\title{
Upgrading Delayed Petroleum Coke Fines by the Use of Pitch Binders
}

\author{
Hassan Al-Haj Ibrahim*, Ali Abdullah \\ Department of chemical Engineering Al-Baath University, Syria \\ *Corresponding author: Sanjim84@yahoo.com
}

Received March 23, 2014; Revised April 18, 2014; Accepted May 03, 2014

\begin{abstract}
Syrian petroleum coke, produced by a delayed coking unit, is characterized by a high percentage of fines which tends to reduce its commercial value. Blending coke fines using appropriate binders, such as bitumen and polyacrylic acid, can lead, however, to an improved coke that is similar in structure, appearance and other properties to better-quality coke lumps. In this work, samples of Syrian coke fines were blended with Polyacrylic acid or bitumen and thermally treated at high temperatures and increased residence time in an inert atmosphere of nitrogen at atmospheric pressure. This treatment led to a general improvement of the petcoke qualities. The rate of desulphurization obtained as a result of the thermal treatment was $88 \%$ for most coke fines. A small overall reduction in the calorific value of the treated coke was also observed, but this was less than $8 \%$ in general.
\end{abstract}

Keywords: petroleum coke, coke fines, thermal treatment, binder

Cite This Article: Hassan Al-Haj Ibrahim, and Ali Abdullah, "Upgrading Delayed Petroleum Coke Fines by the Use of Pitch Binders.” Chemical Engineering and Science, vol. 2, no. 2 (2014): 15-17. doi: 10.12691/ces-2-2-1.

\section{Introduction}

Syrian petroleum coke is produced by the delayed coking unit at the Homs Oil Refinery. This unit was designed and built during the late sixties of last century for the purpose of maximizing gasoline and distillate yields using a feedstock of residue materials.

The coke produced by this unit is characterized by a high percentage of fines. Coke fines may also be generated during the calcination or thermal treatment of the coke. Green petroleum coke must, in most cases, be calcined or treated thermally to a very high temperature (above $1000^{\circ} \mathrm{C}$ ). Thermal treatment of Syrian petroleum coke, in particular, is a necessary step for upgrading the coke and reducing its sulphur content to acceptable levels [3]. Coke particles subjected to very high heating rates tend to burst generating thereby coke fines. This is known as the Popcorn effect. Further, friction between the coke particles themselves during processing or transport or between the particles and other objects or surfaces that come into contact with them cause further generation of coke dust or fines.

The high percentages of coke fines in the Syrian coke produced at the Homs Oil Refinery, as well as its high sulphur content, tend to reduce its commercial value. There seems to be less demand for coke fines than for other types of coke. While coke fines may be easier to burn as a fuel, their use for other applications is not always to be recommended. Furthermore, the creation of coke dust, associated with the presence of coke fines, is a major cause of environmental problems. It results also in loss of productivity.
In many applications, coke fines cannot be used as such, and an agglomerating step is required which would require in turn a suitable binder and a baking step. The final product becomes in many cases a relatively weak lump [1]

The structure of petcoke in general is commonly described in terms of anisotropy where the most needlelike cokes are considered to be the most anisotropic [4]. Coke particle size is an important factor related to particle anisotropy, whereby very small particles are highly anisotropic and very large particles tend to become isotropic for even the most highly oriented cokes, and as a result coke fines are expected to be anisotropic.

For producing bonded coke blocks, coke fines are to be preferred to shot coke as good bonding of shot coke with, for example, pitch seems to be prevented by the slickness of the outer layer of the shot spheres, their lack of porosity and dissimilarity of the outer needle coke layer of the shot sphere which has a very low coefficient of thermal expansion and the interior core of the sphere which, being isotropic, has a very high coefficient of thermal expansion.

Several binders have been used including pitch, Polyacrylic acid, Bentonite clay (which is an inorganic binder with medium compressive strength) and polymer binders with very high compressive strength such as latex enamel, Polyurethane latex and Polyacrylic latex. Scrap tyres have also been used as binder in coke manufacturing. Pitch, however, is to be preferred for availability and economic considerations. Surfactants may be used in the binding process in order to reduce surface forces and achieve maximum packing density.

Bonded blocks of coke fines may be used in several applications. Bonded blocks of carbon have been described by Redfarn et al. [2] for purifying fluids. On physical activation, the adsorptive power of activated 
green coke increased when bonded coke was used and tar pitch used as binding material [6].

\section{Experimental Work}

For the present work, samples of Syrian coke fines were taken from the coke heaps stored to the west of the Homs Oil refinery. Table 1 and Table 2 give the results of the proximate and ultimate analysis for these samples. The coke fines, as can be seen from these results, are characterized by a higher volatile matter content (14.8 as compared to 12.0 for lump coke), higher oxygen content (3.0 as compared with 1.3 for lump coke) and lower $\mathrm{C} / \mathrm{H}$ ratio (16.7 as compared to 18.5 ).

Table 1. Proximate Analyses of Syrian coke fines, Air-dried basis

\begin{tabular}{|c|c|}
\hline Ash (wt. \%) & 0.28 \\
\hline Moisture (wt. \%) & 0.08 \\
\hline Fixed carbon (wt. \%) & 84.80 \\
\hline Volatile Matter (wt. \%) & 14.84 \\
\hline Sulphur (wt. \%) & 7.41 \\
\hline Gross Calorific Value (kJ/kg) & $34.7 \times 10^{3}$ \\
\hline Real density (g/cm ${ }^{3}$ ) & 1.37 \\
\hline Cd (ppm) & Trace \\
\hline Cr (ppm) & 1.6 \\
\hline Co (ppm) & 0.6 \\
\hline $\mathrm{Cu}(\mathrm{ppm})$ & 0.07 \\
\hline $\mathrm{Ni}(\mathrm{ppm})$ & 262 \\
\hline
\end{tabular}

Table 2. Ultimate Analyses of Syrian coke fines, Dry, ash-free basis

\begin{tabular}{|c|c|}
\hline Carbon & 83.4 \\
\hline Hydrogen & 5.0 \\
\hline Nitrogen & 1.2 \\
\hline Oxygen & 3.0 \\
\hline Sulphur & 7.4 \\
\hline C / H (wt.) & 16.7 \\
\hline
\end{tabular}

The coke samples were first pre-wetted with water. This is an important step in order to protect the interior of the small carbon particles and maintain surface area/adsorption properties of the coke. This seems to prevent the binding agent from entering the small micropores and plugging them. In some cases the coke samples were pre-wetted using water in combination with a water-soluble dispersant.

Two different binders were used in the present study, viz. Polyacrylic acid and bitumen from the vacuum distillation unit at the Homs Oil refinery. The bitumen has a high sulphur content $(6.49 \%)$ and a gross calorific value of $40.9 \times 10^{3} \mathrm{~kJ} / \mathrm{kg}$. Its penetration at $25^{\circ} \mathrm{C}$ is 43 .
Samples of the coke fines were mixed with the binder using different weight ratios, and the resulting blends were tested for their sulphur content and calorific value (Table 3 and Table 4). The blended coke fines were similar in structure and physical appearance to coke lumps. For comparison, samples of lump coke were crushed and powdered and then blended with the binder and analysed. The results obtained correspond in general to the values expected for the calculated values using the properties of the coke and the binding material used.

Table 3. Analysis of Syrian coke fines blended with bitumen

\begin{tabular}{|c|c|c|c|c|}
\hline \multirow{2}{*}{$\begin{array}{c}\text { Blending ratio (wt.) } \\
\text { Bitumen/coke }\end{array}$} & \multicolumn{2}{|c|}{$\begin{array}{c}\text { Sulphur content } \\
\text { (wt. \%) }\end{array}$} & \multicolumn{2}{c|}{$\begin{array}{c}\text { Calorific Value }\left(10^{3}\right. \\
\mathrm{kJ} / \mathrm{kg} \text { ) }\end{array}$} \\
\cline { 2 - 5 } & $\begin{array}{c}\text { Coke } \\
\text { fines }\end{array}$ & $\begin{array}{c}\text { Crushed } \\
\text { coke lumps }\end{array}$ & $\begin{array}{c}\text { Coke } \\
\text { fines }\end{array}$ & $\begin{array}{c}\text { Crushed } \\
\text { coke lumps }\end{array}$ \\
\hline $0 / 5$ & 7.41 & 7.29 & 34.7 & 34.9 \\
\hline $1 / 5$ & 6.54 & 6.87 & 35.9 & 35.5 \\
\hline $2 / 5$ & 7.34 & 7.12 & 35.3 & 36.1 \\
\hline $3 / 5$ & 7.32 & 7.36 & 36.6 & 36.7 \\
\hline
\end{tabular}

Table 4. Analysis of Syrian coke fines blended with Polyacrylic acid

\begin{tabular}{|c|c|c|c|c|}
\hline \multirow{2}{*}{$\begin{array}{c}\text { Blending ratio (wt.) } \\
\text { Polyacrylic } \\
\text { acid/coke }\end{array}$} & \multicolumn{2}{|c|}{$\begin{array}{c}\text { Sulphur content } \\
\text { (wt. \%) }\end{array}$} & \multicolumn{2}{c|}{$\begin{array}{c}\text { Calorific Value }\left(10^{3}\right. \\
\mathrm{kJ} / \mathrm{kg})\end{array}$} \\
\cline { 2 - 5 } & $\begin{array}{c}\text { Coke } \\
\text { fines }\end{array}$ & $\begin{array}{c}\text { Crushed } \\
\text { coke lumps }\end{array}$ & $\begin{array}{c}\text { Coke } \\
\text { fines }\end{array}$ & $\begin{array}{c}\text { Crushed } \\
\text { coke lumps }\end{array}$ \\
\hline $0 / 5$ & 7.41 & 7.21 & 34.7 & 34.8 \\
\hline $1 / 5$ & 6.97 & 6.78 & 31.8 & 31.9 \\
\hline $2 / 5$ & 5.58 & 5.43 & 29.2 & 29.3 \\
\hline $3 / 5$ & 5.07 & 4.93 & 28.9 & 29.0 \\
\hline
\end{tabular}

The blends were thermally treated in an inert atmosphere of nitrogen at atmospheric pressure. The treatment was carried out in an electrical tube furnace heated by a SiC element fully covering the working tube. The outside diameter of the working tube is $59 \mathrm{~mm}$, and the heated length is $250 \mathrm{~mm}$. A PtRh-Pt thermocouple is placed in the centre of the heating zone and is lead to the temperature control unit. The conditions used in the treatment were such that would be expected to lead to a maximum rate of desulphurization at moderately high temperatures [3]. Table 5 is a summary of the treatment conditions used. A summary of the results of the thermal treatment is shown in Table 6 and Table 7.

Table 5. Conditions of Thermal Treatment Average weight of treated sample: $10 \mathrm{~g}$

\begin{tabular}{|c|}
\hline Average weight of treated sample: $10 \mathrm{~g}$ \\
\hline Rate of heating: $3.5^{\circ} \mathrm{C} / \mathrm{min}$. \\
\hline Gas atmosphere: $\mathrm{N}_{2}$ \\
\hline Pressure: Atmospheric \\
\hline Rate of nitrogen flow $=0.5 \mathrm{l} / \mathrm{min} / \mathrm{g}$ \\
\hline Residence time at the maximum temperature $=180 \mathrm{~min}$ \\
\hline
\end{tabular}

Table 6. Results of the thermal treatment (Maximum temperature $=1650 \mathrm{~K}$ )

\begin{tabular}{|c|c|c|c|c|}
\hline \multirow{3}{*}{ Binder } & Binder/coke ratio & Type of coke & Wt loss \% & CV $\times 10^{3} \mathrm{~kJ} / \mathrm{kg}$ \\
\hline \multirow{3}{*}{ Bitumen } & $1 / 5$ & \multirow{2}{*}{ Coke fines } & 39 & 33.2 \\
\cline { 2 - 5 } & $2 / 5$ & & 41 & 32.6 \\
\cline { 2 - 5 } & $1 / 5$ & Coke lumps & 35 & 33.1 \\
\hline
\end{tabular}

Table 7. Results of the thermal treatment (Maximum temperature $=1700 \mathrm{~K}$ )

\begin{tabular}{|c|c|c|c|c|c|}
\hline Binder & Binder/coke ratio & Type of coke & Wt loss \% & $\mathrm{CV} \times 10^{3} \mathrm{~kJ} / \mathrm{kg}$ & S wt \% \\
\hline \multirow{2}{*}{ Bitumen } & \multirow{2}{*}{$3 / 5$} & Coke fines & 47 & 32.8 & 0.87 \\
\hline & & Coke lumps & 46 & 32.4 & 0.99 \\
\hline \multirow{2}{*}{ Polyacrylic acid } & $2 / 5$ & \multirow{2}{*}{ Coke lumps } & 28 & 32.8 & 0.63 \\
\hline & $3 / 5$ & & 31 & 31.7 & 0.74 \\
\hline
\end{tabular}

The rate of desulphurization obtained as a result of the thermal treatment varied in general between $86 \%$ for crushed coke lumps blended with bitumen to $88 \%$ for coke fines. This result is not significantly different from 
the results obtained for coke fines in general, where a rate of $89 \%$ sulphur removal was obtained [5].

Similarly, the overall reduction in the calorific value of the treated coke was not affected by the type of coke or the blending material used. An average reduction of 6-8\% was obtained. This also compares well with the results obtained for coke fines [5].

\section{Conclusion}

It is clear from the results obtained that blending coke fines using appropriate binders, such as bitumen and polyacrylic acid, lead to a type of coke that is similar in structure, appearance and other properties to coke lumps. Similar results were obtained on thermally treating the blended coke fines to the results obtained on treating normal coke fines.

\section{Reference}

[1] H. H. Brandt and R. S. Kapner; Desulphurization of petroleum coke, Light Metals, 1984, pp. 883-887.

[2] Redfarn, C.A., and J. Bedfrod, U.S. Patent 4,000,236.

[3] H. Al-Haj Ibrahim and M. M. Ali; The effect of increased residence time on the thermal desulphurization of Syrian petroleum coke, Periodica Polytechnica Ser. Chem. Eng., Vol. 48, No. 1, 2004, pp. 53-62.

[4] E. A. Heintz; The characterization of petroleum coke, Carbon, vol. 34, No. 6, 1996, pp. 699-709.

[5] H. Al-Haj Ibrahim, Characterization and thermal treatment of Syrian petcoke fines, $1^{\text {st }}$ International chemical engineering conference, Homs, Syria, 10-12 Feb, 2009, pp. 83-93.

[6] S. Nurlatifah and T. I. Pudiyanto, Development technique in the activation process of petroleum coke 'Spring national meeting of the American Chemical Society, New Orleans, LA (United States), 24-28 March, 1996, Preprints of Papers, ACS, Division of Fuel Chemistry ; Vol. 41 ; Issue 1). 